\title{
Experience of growing soybeans (Glycine max (L) merryll) on irrigation in the unstable moisture zone of the Stavropol Territory
}

\author{
Olga Shabaldas ${ }^{1, *}, K_{\text {Konstantin Pimonov }}^{2}$, Olga Vlasova ${ }^{1}$, and Vera Perederieva ${ }^{1}$ \\ ${ }^{1}$ Stavropol State Agrarian University, 12 Zootehknicheskiy lane, Stavropol, Russia, 355000 \\ ${ }^{2}$ Don State Agrarian University, 24 Krivoshlykova str., Persianovskiy town, Oktyabrskiy district, \\ Rostov region, Russia, 346493
}

\begin{abstract}
To obtain a stable harvest of high quality grain, Agrosakhar LLC, located in the Stavropol Territory, used soybean growing technology, which included: the use of modern energy and resource-saving equipment for soil cultivation, sowing and harvesting, cultivation of adapted varieties bred in Russia and Canada - Selecta 302, Vilana, Furio, Kofu, Kyoto, Kanata; introduction of complex fertilizer - azophoska for main soil cultivation, pre-sowing seed treatment with a fungicidal dressing agent Delit Pro and the inoculant Highcoat Super Soy. The system of protective measures included a combination of agrotechnical measures using chemical plant protection products based on monitoring of harmful objects. To combat monocotyledonous and dicotyledonous species of weeds, sowing was treated with Pledge herbicide before germination, followed by a tank mixture of herbicides Bazagran with Harmony in the phase of the first true leaf in soybean plants. The use of the fungicide Akanto Plus together with Karate Zeon and Ampligo Plus ensured effective protection of soybean plants from diseases and pests during the growing season. The technology used for growing soybeans on the farm enables you to consistently get a large and high-quality grain yield. The maximum yield of $2.92 \mathrm{t} / \mathrm{ha}$ was obtained by sowing the Kofu variety using the developed cultivation technology. On average, the yield of protein amounted to 0.98 , and vegetable fat amounted to $0.59 \mathrm{t} / \mathrm{ha}$. The profitability of soybean grain production on the farm using this cultivation technology is $44.2 \%$.
\end{abstract}

Production of vegetable protein, both globally and domestically, is an urgent trend in the field of crop production. Solving problems related to the increase in vegetable protein production through cultivation of grain legumes makes it possible to provide the population with food, and also the livestock industry with high-grade and high-quality feed. Soybeans are of particular importance in the group of grain legumes [1, 3].

Over the past 30 years, the soybean crop area in the Russian Federation has been steadily increasing. In 1990, it amounted to 664 thousand hectares, and by 2019 it increased 4.6 times (the sown area is 3079 thousand hectares). Over the past ten years, the average annual increase in the sown area in Russia has been $13.4 \%$. An analytical review shows that

* Corresponding author: shabaldas-olga@mail.ru 
the volume of soybean grain production in the Russian Federation in 2010 amounted to 1226 thousand tons, by 2014 it increased to 2605 thousand tons. The gross harvest of industrial legumes reached record values in 2019 - 4645 thousand tons, which indicates an increase in soybean grain production over the past 5 years by $78.3 \%$, and over the past 10 years by $391.2 \%$. In 2019, the sown area of soybeans in the Stavropol Territory amounted to 23.4 thousand hectares (which is at the level of average annual data), the gross harvest was 30 thousand tons with a yield of $13.6 \mathrm{c} / \mathrm{ha}[2,4,5]$.

It should be noted that the yield and gross yield of soybeans largely depend on the prevailing weather conditions, however, compliance with the agrotechnical features of growing this crop and taking into account its biological characteristics play a significant role, monitoring and regulation of which will enable us to obtain stable high quality yields [6 - 13].

The production experiment was carried out under the conditions of Agrosakhar LLC, on ordinary black soil, located in the zone of unstable moisture in the Stavropol Territory. The main elements of soybean cultivation technology at the production site are the use of the best forecrops, high-quality soil cultivation using modern energy and resource-saving equipment, the use of fertilizers, the use of varieties of domestic and foreign selection, high-quality seed preparation, optimal sowing times, protective measures in the fight against weeds, diseases and pests.

Soybeans are grown in a seven-field grain crop rotation: sugar beets, winter wheat, soybeans, grain corn, winter barley, soybeans, and winter wheat. The forecrops are winter crops (wheat and barley), which vacate the field early. After harvesting winter wheat, the soil was cultivated with a disc harrow - Salford 870-26.2 to a depth of 14-16 cm; when using this tool, the surface is actively and efficiently leveled, plant residues are crushed and mixed with the soil. In autumn, the soil was loosened with a universal cultivator Köckerling vector-620 boxer 3000 (up to $40 \mathrm{~cm}$ ) with a simultaneous introduction of azophoska at a dose of $\mathrm{N}_{34} \mathrm{P}_{34} \mathrm{~K}_{34}$. In the spring, with a physical ripeness of ordinary black soil, it was loosened with a pre-sowing wide-cut cultivator Wil-Rich 13 EXC to a depth of 4-5 cm.

For sowing, Primera DMC 9000 seeder was used, a variety of Russian selection: Selecta 302 (Soybean complex 'SOKO') and varieties of Canadian selection: Furio, Kofu, Kyoto and Kanata were sown. The seeding rate was 0.55 for the early-ripening Furio variety, for the mid-ripening varieties: Selecta 302, Kofu and Kyoto - 0.50, and for the mid-lateripening variety Kanata -0.45 million pcs/ha of germinating seeds. The sowing was carried out at the recommended time for the cultivation zone in the 3rd decade of April - 1st decade of May.

Soybeans were irrigated with a Valley sprinkler, with an estimated irrigation rate that averaged 300-350 $\mathrm{m}^{3} / \mathrm{ha}$, depending on the precipitation during the growing season. In the fight against harmful objects, soybean crops were treated with an Amazone UX-4200 5200 sprayer, the rate of application of the working solution was $200 \mathrm{l} / \mathrm{ha}$.

Before harvesting, soybean plants were treated with a desiccant - Reglon Forte BP, 2.0 1/ha. Harvester Torum-750 was used for harvesting.

In the field crop rotation of Agrosakhar LLC during the survey, the species composition of weeds from various biological groups was determined. Annual dicotyledons were present - Ambrosia wormwood, White Mary, Shchiritsa upturned and zmindoid, Hibiscus trifoliate, Durnishnik ordinary; perennial dicotyledons - Sage lanceolate; perennial suckers Field sow thistle (yellow); annual cereals - Chicken millet (common barnyard), as well as a quarantine weed - Serrated spurge. By biological groups, weeds are distributed as follows: juvenile wintering weeds accounted for $8.9 \%$, one-year early spring weeds $13.5 \%$, perennial rhizomatous and root-sprouting $10.2 \%$, the largest number fell on one-year late 
spring weeds $67.4 \%$ (Figure 1.) In connection with the present species and quantitative composition, a scheme for the use of herbicides in soybean crops was developed.

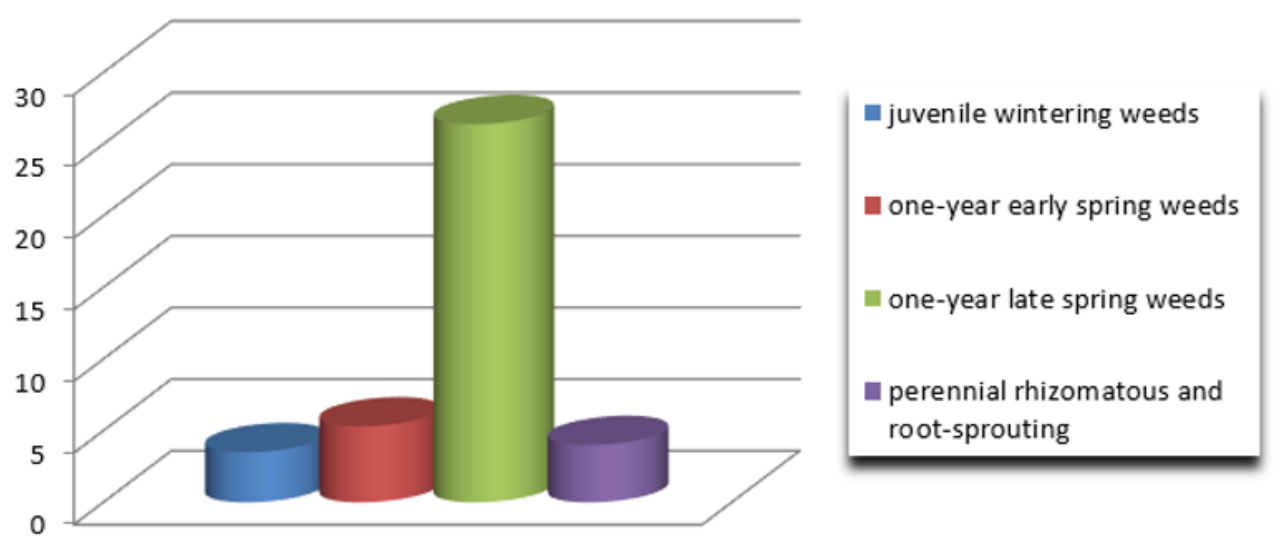

Fig. 1. Number of weeds by biological groups, $\mathrm{pcs} / \mathrm{m}^{2}$

In the fight against weeds, sowing of soybeans before germination was treated with the Pledge SP systemic herbicide (500 g/kg of flumioxazine), $0.12 \mathrm{~kg} / \mathrm{ha}$ (against dicotyledonous and partially cereal weeds). In phase 1 , the trifoliate leaf of soybean plants was treated with a tank mixture of contact herbicides - Bazagran VKR (48 g/l bentazone), 2 l/ha and systemic action - Harmony STS (750 g/l thifensulfuron-methyl) $0.008 \mathrm{~kg} / \mathrm{ha}$ (against dicotyledonous weeds). In the years of active distribution of cereal weeds, the systemic herbicide Legion Kombi KE (240 g/l kletodim) was used at a dose of 0.6 l/ha.

Monitoring and timely diagnosis of pests and diseases carried out on the farm, as well as average annual counting rates, enable the use of timely protective measures using effective insecticides and fungicides.

Table 1. Distribution of pests in soybean crops in the conditions of Agrosakhar LLC, 2018-2020.

\begin{tabular}{|l|c|c|c|c|c|c|c|c|c|c|c|c|}
\hline \multicolumn{10}{|c|}{ Pest } & \multicolumn{9}{|c|}{ May } & \multicolumn{3}{|c|}{ June } & \multicolumn{3}{c|}{ July } & \multicolumn{3}{c|}{ August } \\
\cline { 2 - 14 } & I & II & III & I & II & III & I & II & III & I & II & $\begin{array}{c}\text { II } \\
\text { I }\end{array}$ \\
\hline Weevils & $*$ & $*$ & $*$ & $*$ & $*$ & $*$ & & & & & & \\
\hline Aphids & & $*$ & $* *$ & $* *$ & $*$ & $*$ & $*$ & & & & & \\
\hline Meadow moth & & & $*$ & $* *$ & $* * *$ & $*$ & & & $*$ & $*$ & $* * *$ \\
& & & & $*$ & & & & & & $*$ & & \\
\hline $\begin{array}{l}\text { Leaf-eating } \\
\text { scoops }\end{array}$ & & & $*$ & $* *$ & $* *$ & $* *$ & $* *$ & $*$ & $*$ & $*$ & & \\
\hline $\begin{array}{l}\text { Acacia (legume) } \\
\text { moth }\end{array}$ & & & & & & & & & $*$ & $*$ & $* * *$ & $*$ \\
\hline Spider mite & & & & & & $*$ & $\begin{array}{c}* * \\
*\end{array}$ & $* *$ & $* *$ & $*$ & $* *$ & $*$ \\
\hline
\end{tabular}

*** - period of harmfulness of pests

Protection of soybeans from pests was carried out when they reached the economic threshold of harmfulness. The crops were treated with insecticides Karate Zeon MKS (50 g/l Lambda-cyhalothrin), (0.3 l/ha), if the threshold of harm of the leaf-eating scoops was 
exceeded, the crops were additionally treated with Ampligo Plus MKS (50 g/ lambdacyhalothrin $+10 \mathrm{~g} / \mathrm{l}$ chloranthraniliprol ( $0.25 \mathrm{l} / \mathrm{ha})$.

The most common fungal diseases of soybeans under irrigation conditions on the farm are: Fusarium seedling (Fusarium oxysporum (Schlecht.) Snud Et Hans. etc.), peronosporosis (Peronospora manshurica (Naum.) Sud.), ascochitis (Ascochyta sojaecola Abramov.), septoria (Septoria glycines Hemmi.). To prevent the development of diseases, soybean seeds were treated with the fungicidal dressing agent Delit Pro KS (200 g/l pyraclostrobin), (0.5 l/ha) together with the inoculant Highcoat Super Soy (Bradyrhizobium japonicum, 2 x 109 (2 billion bacteria) / 1 g peat), (0.3 l/ha) + Highcoat Super Extender (1,2benzisothiazol-3 $(2 \mathrm{H})$-one), (1.42 l/ha). In the budding phase, soybean crops were treated with the fungicide Akanto Plus KS (200 g/l picoxystrobin + 80 g/l cyproconazole) (0.6 l/ha).

The applied elements of the technology of growing soybeans in Agrosakhar LLC made it possible to obtain grain yield (depending on the variety) in the range of 24.5 - 29.2 t/ha (Table 2).

Table 2. Yield and quality of soybeans grown in Agrosakhar LLC, average for 2018 -2020.

\begin{tabular}{|l|c|c|c|c|c|}
\hline Variety & \multirow{2}{*}{$\begin{array}{c}\text { Productivity, } \\
\text { t/ha }\end{array}$} & \multicolumn{2}{|c|}{ Content \% } & \multicolumn{2}{c|}{ Harvest, t/ha } \\
\cline { 3 - 6 } & & protein & vegetable fat & protein & vegetable fat \\
\hline Selecta 302 & 2.84 & 37.0 & 22.1 & 0.94 & 0.56 \\
\hline Furio & 2.63 & 38.1 & 20.3 & 0.90 & 0.48 \\
\hline Kofu & 2.92 & 37.3 & 22.6 & 0.98 & 0.59 \\
\hline Kyoto & 2.45 & 38.5 & 21.5 & 0.85 & 0.47 \\
\hline Kanata & 2.70 & 39.6 & 21.4 & 0.96 & 0.52 \\
\hline Total & 2.71 & 38.1 & 21.6 & 0.93 & 0.53 \\
\hline
\end{tabular}

The indicators of biochemical analysis of soybean grain showed that the protein content varied depending on the variety from 37.0 to 39.6 , and vegetable fat from 20.3 to $22.6 \%$, the average protein content for the varieties was 38.1, vegetable fat $-21.6 \%$. As a result of the obtained yield and the content of protein and vegetable fat, collection of protein per unit area averaged $0.93 \mathrm{t} / \mathrm{ha}$, vegetable fat $-0.53 \mathrm{t} / \mathrm{ha}$.

Of course, in addition to improving and implementing the technological process of growing soybeans, it is necessary to take into account the economic component of its production. In Agrosakhar LLC, the current conditions for growing soybeans, a part of which is the use of modern high-quality equipment in soil cultivation, sowing and caring for crops, sowing with high-quality seeds of promising varieties adapted to environmental conditions, the use of fertilizers and inoculation of seeds with a bacterial preparation, and also plant protection products in the fight against harmful objects, irrigation of crops and reducing the risk of crop loss - desiccation and timely harvesting enable you to get profitable soybean grain. Production costs for growing soybeans amounted to 41,664.3 rubles per 1 hectare, with a cumulative selling price of 23,000 rubles for grain, sales proceeds amounted to 75,842.5 rubles, and the profit per hectare was 18,423.2 rubles. The profitability of soybean grain production in production conditions on average for 3 years was $44.2 \%$.

Thus, the cultivation of soybeans in a zone of unstable moisture during irrigation at Agrosakhar LLC in Izobilnensky District of Stavropol Territory using the developed technology, including cultivation of new promising varieties, modern technology, a fertilizer system, high-quality seed preparation with a simultaneous use of fungicides and inoculating seeds with a bacterial preparation, carrying out protective measures taking into account biological characteristics and monitoring harmful objects, it is possible to obtain 
not only a guaranteed high-quality yield, but also to ensure economically viable production of soybean grain. The largest harvest was obtained on average for 2018 -2020 by mediumearly varieties, such as Select 302 and Furio - $2.84-2.92 \mathrm{t} / \mathrm{ha}$, the collection of protein was $0.94-0.98$, and vegetable fat $-0.56-0.59 \mathrm{t} / \mathrm{ha}$.

\section{References}

1. Balakay G.T., Selitskiy S.A. Productivity of soybean varieties with sprinkling and drip irrigation systems in the conditions of the Rostov region. Scientific journal of the Russian Research Institute of Melioration Problems. 2019. No. 3 (35). pp. 80-97.

2. Sown area of soybeans in Russia. Results of 2019. - Electronic resource / https://abcentre.ru/news/posevnye-ploschadi-soi-v-rossii-itogi-2019-goda.

3. Zaitsev N.I., Bochkarev N.I., Zelentsov S.V. Prospects and directions of soybean breeding in Russia in the context of implementation of the national strategy of import substitution. Scientific and technical bulletin VNIIMK. 2016. Issue. No. 2 (166). pp. 311.

4. Baranov V.F., Correa U.T. Varietal specificity of soybean cultivation. Krasnodar: VNIIMK. 2007. 84 p.

5. Borodychev V.V. Agrotechnical factors of effective use of water resources in the cultivation of irrigated soybeans. Problems of development of the agro-industrial complex of the region. 2019. No. 2 (38). pp. 35-42.

6. Borodychev V.V., Lytov M.N. Features of the use of mineral fertilizers in the cultivation of soybeans with irrigation in the lower Volga region. Fertility. 2015. No. 1 (82). pp. 33-35.

7. Vorontsov V.A. Soybean productivity depending on the main tillage and chemical means. Legumes and cereals. 2016. No. 3 (19). pp. 77-81.

8. Krivoshlykov K.M., Roshchina E.Yu., Kozlova S.A. Analysis of state and development of soybean production in the world and in Russia. Oil crops. Scientific and technical bulletin of the All-Russian Scientific Research Institute of Oilseeds. 2016. Issue 3. (167) pp. 64-69.

9. Productivity of cultivated soybean varieties of the southern ecotype cultivated on ordinary black soil in dry conditions. Bulletin of APK Stavropol. No. 1 (37) 2020, pp. 79-84.

10. Productivity of soybean varieties of different ripeness groups in the eastern zone of Krasnodar Krai. O. G. Shabaldas, N. I. Zaitsev, K. I. Pimonov and others. Agriculture. 2019. No. 7. pp. 38-40. DOI: 10.24411 / 0044-3913-2019-10710.

11. Ways of improving the elements of soybean cultivation technology. G.T. Balakay, L.M. Dokuchaeva, R.E. Yurkova, S.A. Selitskiy. Scientific journal of the Russian Research Institute of Land Reclamation Problems. 2019. No. 4 (36). pp. 100-120.

12. Symbiotic activity and productivity of soybean, depending on the methods of presowing treatment of soybean seeds in the conditions of central ciscaucasiaShabaldas O.G., Golub A.S., Zelenskaya T.G., Donets I.A., Mukhina O.V. Research Journal of Pharmaceutical, Biological and Chemical Sciences. 2018. T. 9. № 4. C. 688-691.

13. Biological features and productivity of soybean varieties grown in the unstable moisture zone on leached chernozem, Shabaldas O.G., Donets I.A., Golub A.S., Mukhina O.V., Chukhlebova N.S. IOP Conference Series: Earth and Environmental Science. III International Scientific Conference: AGRITECH-III-2020: Agribusiness, Environmental Engineering and Biotechnologies. Krasnoyarsk Science and Technology City Hall of the Russian Union of Scientific and Engineering Associations. 2020. C. 52072. 